This is an Open Access article, distributed under the terms of the Creative Commons Attribution licence (http://creativecommons.org/licenses/by/4.0/), which permits unrestricted reuse, distribution, and reproduction in any medium, provided the original work is properly cited.

\title{
The Bronze Age, a World of Specialists? Metalworking from the Perspective of Skill and Material Specialization
}

\author{
Maikel H. G. KuIJPERS \\ Faculty of Archaeology, Leiden University, The Netherlands
}

This article starts from the observation that the social persona of 'specialist' is an important analytical unit in archaeology, typically to model social (craft) organization from a Marxist perspective. This has caused this concept to solidify around economic rather than material concerns. I argue that the 'specialist' has become too much an ideational concept that is no longer accurately rooted in archaeological artefacts. Hence, through a brief exploration of Early Bronze Age axes, my aim is to highlight technical skill and use this to reveal different levels of material specialization. On this basis, I suggest moving beyond the umbrella term of 'specialist' and using four, more precise analytical units that are better equipped to accommodate the qualitative diversity of material cultures: the amateur, showing basic knowledge but little refinement; the craftsperson, producing well-made practical objects; the master, striving for perfection and setting the norm; and the virtuoso, taking risks in creating original and unique products.

Keywords: specialist, material specialization, craft theory, skill, Bronze Age, chaîne opératoire

\section{INTRODUCTION}

The concept of 'specialist' and its derivatives ('specialized' and 'specialization') indiscriminately accommodate different concerns associated with craftspeople and production. Among these let us note the level of craftsmanship, the importance and scarcity of the materials used, knowledge and skills, economical and time constraints, social roles, affiliation, gender division, and the spatial unit of analysis (e.g. Brumfiel \& Earle, 1987; Costin, 1991, 2001; Helms, 1993; Costin \& Wright, 1998; Hruby \& Flad, 2007; Sofaer, 2010).

In Bronze Age research, the use of this terminology is even extended to designate occupational roles such as warriors, priest, and traders in an attempt to model Bronze
Age trade within the framework of a political economy (Earle et al., 2015; Kristiansen \& Earle, 2015; Kristiansen \& Suchowska-Ducke, 2015; Kristiansen, 2017). Given the copious use and the fundamental role of specialists and their skills in this model, it would be good to know on what archaeological grounds such designation is made, and what it means to be specialized.

A recent comparative study of craft at three European Bronze Age sites-Százhalombatta-Földvár in Hungary, Thy in Denmark, and Monte Polizzo in Italyshowed considerable diversity in the production of ceramics, chipped and ground stones, worked bone, and architecture (Sofaer, 2010). Especially detailed studies of ceramic production at Százhalombatta-Földvár led 
to insights into the development and different levels of skill (Sofaer, 2006; Budden, 2008; Sofaer \& Budden, 2013). Yet, when it comes to describing the social organization of production, these detailed observations are blunted because the terminology allows for little more nuance than a distinction between specialists and non-specialists (Sofaer, 2010: 209-12).

In this configuration, the specialist/nonspecialist categorization is used to model social development through the socio-economic building block of craft specialization, and used to explain increased complexity and social inequality (Brumfiel \& Earle, 1987; Earle \& Kristiansen, 2010). Bronze Age metalworkers are an excellent case study through which one can question the current use of the concept of specialists, because such persons are resolutely described as skilled specialists (e.g. Childe, 1963; Ottaway, 2001; Bertemes, 2004; Kristiansen \& Larsson, 2005; Vandkilde, 2007; Nessel, 2012; Olausson, 2013). Moreover, since Childe's The Dawn of European Civilization, the metalworker has been at the forefront of Europe's distinctive development towards capitalism (Rowlands, 1984). Currently, the focus has shifted to prestige goods, and the skilled metalworking specialist appears to serve largely political-economic concerns of an elite operating in a network of wealth exchange (Earle et al., 2015; Vandkilde, 2016). Within these, noticeably Marxist, perspectives a distinction between specialist and non-specialist suffices, even though it fails to address skill not merely as social capital but a concept worth of enquiry itself.

How much skill is needed to become a specialist? The threshold between the two textual premises of specialists versus nonspecialists is far less clear-cut than the distinction suggests (i.e. essentially a Sorites paradox). It is, for instance, unclear how one ought objectively to recognize a high standard within archaeological material.
Moreover, the distinction echoes and partly maintains a particular insufficiency of twentieth-century social theory: the idea that a clear separation between producers and consumers is possible (Ritzer, 2010). This binary logic oversimplifies complexities such as cross-craftsmanship (Brysbaert \& Gorgues, 2017), the creation of value (Graeber, 2001), and the notion of 'prosumers' that has yet to enter the archaeological discussion (Ritzer, 2010).

\section{The specialist-specialization debate}

Let me first outline which aspects of the specialist-specialization debate I wish to tackle. Specialization in its simplest definition-the idea that fewer people make a class of objects than use it (Costin, 1991: 43, 2001: 276) - is not in question here. Not everybody would have been producing equal amounts of metal artefacts even if the knowledge was freely available, which it probably was not (Hansen, 2013, 2016). Some regions yield copious metalworking evidence, while others are virtually devoid of it. Moreover, it is clear that some metalworkers possessed superior technical skills, commonly related to specialization (Rowlands, 1971: 218). The metalworkers responsible for objects like the Nebra disc or Apa-Hadjúsámson sword were undoubtedly specialists in working metal. My argument is that, while we are accurately documenting this side of the spectrum, we lose sight of the rest. The objects I would like to focus on are those that fill hundreds of pages of the Praebistorische Bronzefunde series: axes, sickles, spears, daggers, simple ornaments, and tools such as chisels and awls. They exhibit a vast variety in quality and therefore cannot all have been made by skilled specialists, or at least they were not specialists on a similar level. Evidently, the term specialist does not allow the material to speak for itself. 
The problem of base criteria for recognizing a specialist in the archaeological record is well-known. The differentiation between specialist and non-specialist centres mostly around three criteria: intensity, compensation, and skill (Costin, 2001: 275-79). The first and second premises are, however, also used to determine specialization in socioeconomic terms. Full-time specialists are thought to produce for a demanding market, and are dependent on a compensation for their subsistence. This leads to an all too easily made assumption that material specialization (skill) will inevitably lead to economic specialization, or vice-versa. As a result, we often see the conflation of the concepts of specialist and craft specialization. A further and more pressing issue is that both the amount of time spent crafting (intensity) and the type and amount of compensation are hard to assess archaeologically. This leaves only the defining criteria of skill as an archaeologically recognizable variable that can be operationalized in the data. Thus, I separate material specialization, which we can examine archaeologically, from economic specialization that we have to infer.

Costin (2001: 283) warns us that evaluating skill is a highly subjective assessment, often incorrectly judged from the supposed quality of an object. This involves making a reference to what we think is the ideal shape of that object (Darmark, 2010; Kuijpers, 2015a). The topic of skill is, thus, easily claimed by cultural relativism (Bleed, 2008: 154). Perhaps this is one of the reasons why archaeologists tend to shy away from judgement regarding technical skill, and simply see everything as made by a skilful specialist.

While there is a cautionary message that we should take away from cultural relativism, it is not helpful if it leads to the suspension of any further questioning. The relationship between skill and quality is not straightforward. There are complexities such as context and purpose. Both may affect the tolerance of mistakes and how we evaluate skill (Kuijpers, 2015a, 2015b). Depending on the purpose of the axe, some of the observed mistakes may be irrelevant. For instance, the fact that the axe from Glattfelden in Switzerland was deposited on the banks of the Rhine (Abels, 1972: 82) might have allowed for the casting error in the blade (see Martinón-Torres \& Uribe-Villegas, 2015; see below). An axe from the Sennwald-Salez hoard in north-eastern Switzerland (Bill, 1997), made of a very particular composition, might not have served as an axe at all but rather a simulacrum (Kuijpers, 2015b) or ingot (Krause, 1988; for a thorough discussion, see Kienlin, 2006).

I will work from the assumption that each of the eight axes below was made by one individual. Apprenticeships, and cross-craftsmanship are but two models that complicate this assumption. Moreover, there is the possibility that a single craftsperson would produce elaborate axes for special purposes and axes of poorer quality for more ordinary purposes (Olausson, 2008). For the moment, however, I shall leave these considerations aside. Before we can tackle such complexities, we first need to acknowledge that there are qualitative differences between objects that archaeologists have so far failed to explain. For this we need a framework, a language, and a categorization of material specialization on the basis of skill.

\section{Economic Specialization}

Despite the problems connected with defining the criteria of economic specialization (Costin, 2001, 2007; Kuijpers, 2008: 31 , this type of specialization has been explored extensively under the heading of craft specialization. This has taken the 
form of discussions of part-time or fulltime specialists, attached to or independent of elites, and household or workshop production (Brumfiel \& Earle, 1987; Kristiansen, 1987; Kristiansen \& Larsson, 2005). An implicit, yet basic, tenet of these studies is that time is understood to be economically valuable.

To master a craft one needs to be able to spend a considerable amount of time practising it (Olausson, 2017). It is this understanding of craftsmanship that sparked ideas about socio-economic specialization and labour divisions; you need to be exempt from other occupational duties to become skilled (Childe, 1963: 4, 10, 1965: 136). Though it is obviously true that much time, effort, and practice need to be invested to become skilled, this by no means equals full-time or even parttime occupation with a craft. Even within contemporary society, our time is taken up mostly by full-time jobs, but this does not in any way keep people from becoming skilled in music, sports, furniture making, knitting, jewellery, or any other field or craft. As a general rule, it is said to take about 10,000 hours of experience to become skilled at any given practice (Sennett, 2009: 172; Kahneman, 2012: 238). Evidently, such generalization fails to address the issue properly, and it should be noted that contemporary craftspeople generally perceive their engagement with material as a lifetime of learning (Adamson, 2007; Wendrich, 2012: 12). The point I wish to make is that - though likely - there is no inherent association between a high level of skill and specialization, and no need for any kind of socio-economic specialization to become skilled (cf. Olausson, 2017).

As a further matter, the supposed amount of time spent on specific techniques and the craft as a whole is used as a 'measurement' of the level of skill present and the value of the product (Costin, 2001). This association between time and skill is a problematic attempt to infer (and quantify) skill via (modern) economic assumptions, such as the maxim that 'time is money'. Again, this axiom is challenged even within capitalist contexts. Time seems of little consideration to craftspeople when practising their craft, and the amount of time spent crafting bears no equivalence in the difficulty of the skill used or the economic value of these skills (Crawford, 2009: 112-15; Sennett, 2009: 251). Besides, a more experienced craftsperson is likely to spend less time on a task than his inexperienced counterpart. There is, thus, an inverted relationship between gaining expertise and the value of this expertise if it were solely measured in units of time.

There is no need to completely reject the association between material specialization and socio-economic specialization. After all, time is spent. But caution is needed when assuming a direct relationship. Through uncritically applying causal correlations between skill, time, specialization, and labour division, archaeologists stretch the limits of their data. What might be strong evidence for specialization-for example, a large metalworking furnace inside a house-is oblique evidence of labour division, and not evidence for making a case about skill. There is a risk of asserting skills on the basis of a social theory rather than demonstrating them in the material (Costin, 2001: 282, 2007: 145).

I nevertheless accept the (economic) theorem that an object with a high level of skilfulness would, accordingly, be attributed value and could endow both its maker and its owner with a certain social status. Differences in quality visible in the material, thus, matter because they are likely to be the result of varying levels of skill, and this points to different craftspeople. There is little reason to deny prehistoric people the ability to recognize and value variation in skill, especially among those people able 
to work in similar crafts and thus knowledgeable about crafting skills. However, value is created in ways beyond the amount of labour and time needed to produce goods. The right actions and performance matter (Lambek, 2013), as do when and by whom the goods are consumed, and for what purpose (Naveh \& Bird-David, 2014). Craftsmanship is much more than the mere production of commodities (Graeber, 2001; Cordes, 2005; Crawford, 2009; Sennett, 2009).

\section{Material Specialization}

In the following section, I focus strictly on technical skill, an aspect of material specialization that, in contrast to ideas about economic specialization, can be assessed through careful analyses of archaeological material, such as the Early to Middle Bronze Age axes from the North Alpine region (Figures 1 to 8 ) which are the subject of this article.

First, an archaeologically workable definition of skill is needed, on the basis of which differences in the level of skill can be demonstrated. Skill is the ability to recognize and respond to the qualities of one's material. Qualities in this respect are the physical properties of the material, but more so the manner in which these properties are perceived as affordances of the material. In the case of metal, Bray reintroduced the term 'metalleity' to emphasize this aspect and to focus on metal as a package of attributes that are potentially available to human society (Bray, 2012; see also Untracht, 1969, 5-6; Mödlinger et al., in press). A skilled craftsperson will bring out the qualities of a material, whereas an unskilled one may not even recognize them.

The difficulty with this definition is that it does not allow for a straightforward quantitative analysis of skill. Dissimilar copper compositions of axes lead to idiosyncratic behaviour of the material; and a skilful response, thus, results in dissimilar applications of certain techniques. In other words, skill is not static, and using a similar technique can be a sign of skill when applied to one axe, but a lack of it in another. To reveal skill systematically, it is, thus, necessary to examine many individual axes in their own right and with respect to the specific qualities of the material from which they were made. As this is too large a scope for a single article, here, I make use of few exemplary axes from a study of several hundred (Kuijpers, 2017). These particular axes were chosen because they present obvious mistakes and a considerable diversity of techniques through which differences in skill are visible. They allow me, despite the small sample size, to clarify how and why I have broken down the concept of the 'specialist' and to propose a more nuanced interpretation of the products of craftsmanship.

\section{The good, the bad, and the ugly}

Some of the axes discussed below have been examined as part of Tobias Kienlin's (2008, 2010) enquiry into the cognitive aspects of prehistoric metalworking technology. His studies provide the detailed metallographic data through which different responses to material qualities can be accurately documented. However, macroscopic examination of these axes already reveals much about skill.

In Figure 1 and 2 two axes are presented; they are of the same type (type Lausanne) but with slight differences. The most obvious of these is the additional decoration on axe 281 from Kadañ in the Czech Republic (axe numbers refer to my own database; Figure 1). Instead of addressing this difference in terms of typological variation, I am interested in what 
(a)

(b)

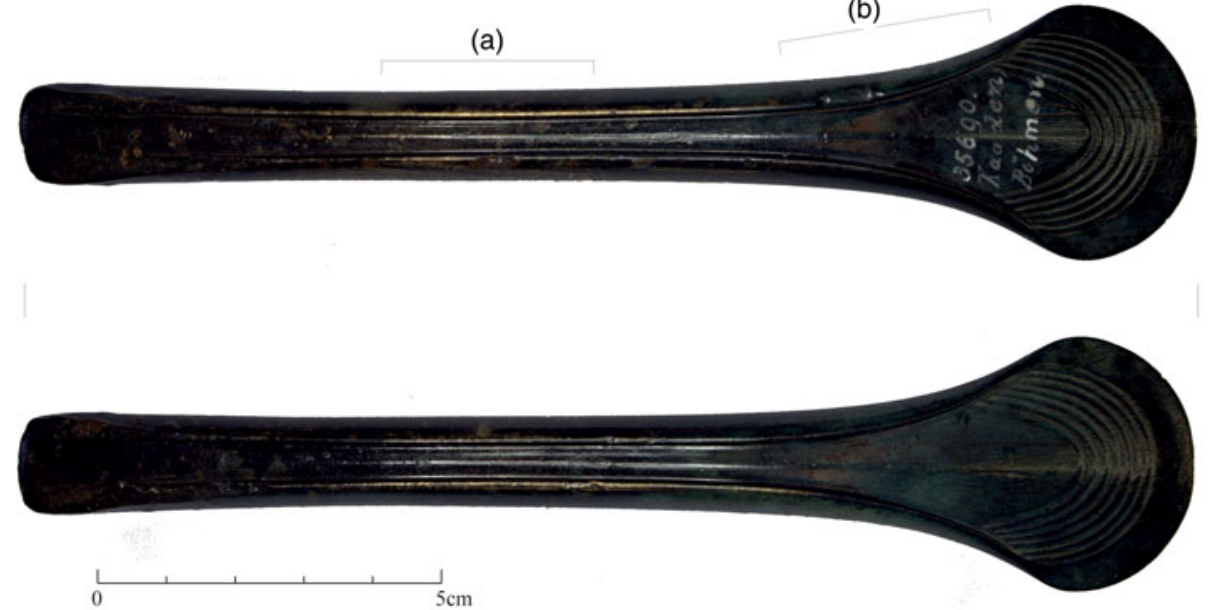

(a)
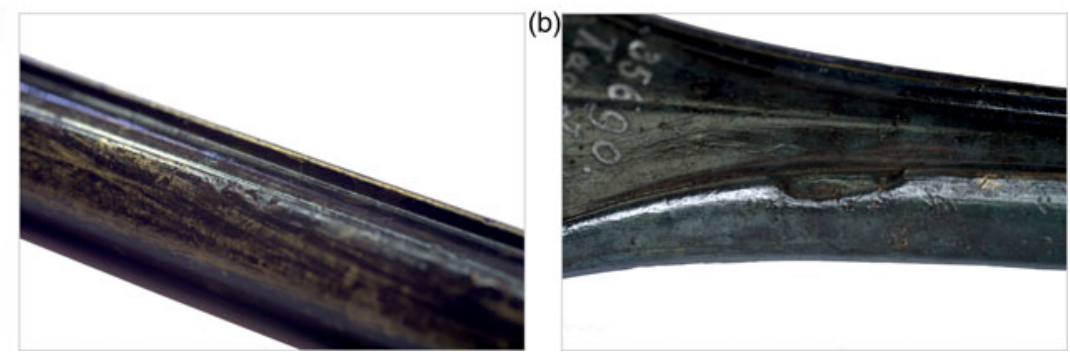

Figure 1. Axe 281, a type Lausanne from Kadañ in the Czech Republic, stray find. The axe has a sharp blade, is very well polished, decorated, and has a remarkable symmetry overall. Photographs by the author, courtesy of the Naturhistorisches Museum Wien.

this means in terms of skill. The decor- the uneven dents; although we cannot ation was probably made after casting, by exclude the possibility that the decoration chiselling and subsequently grinding away had been conceptualized beforehand and

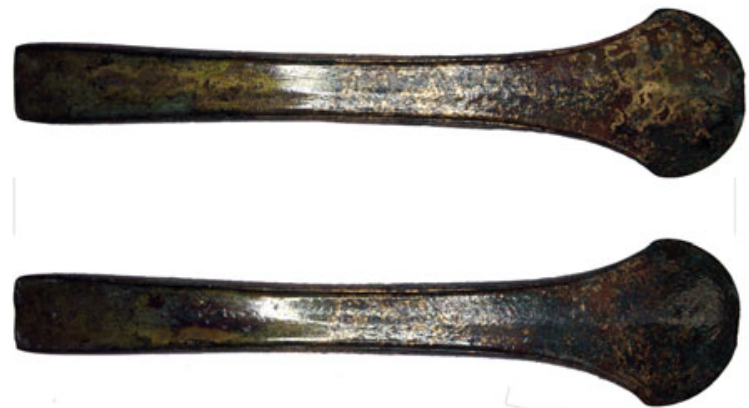

(a)
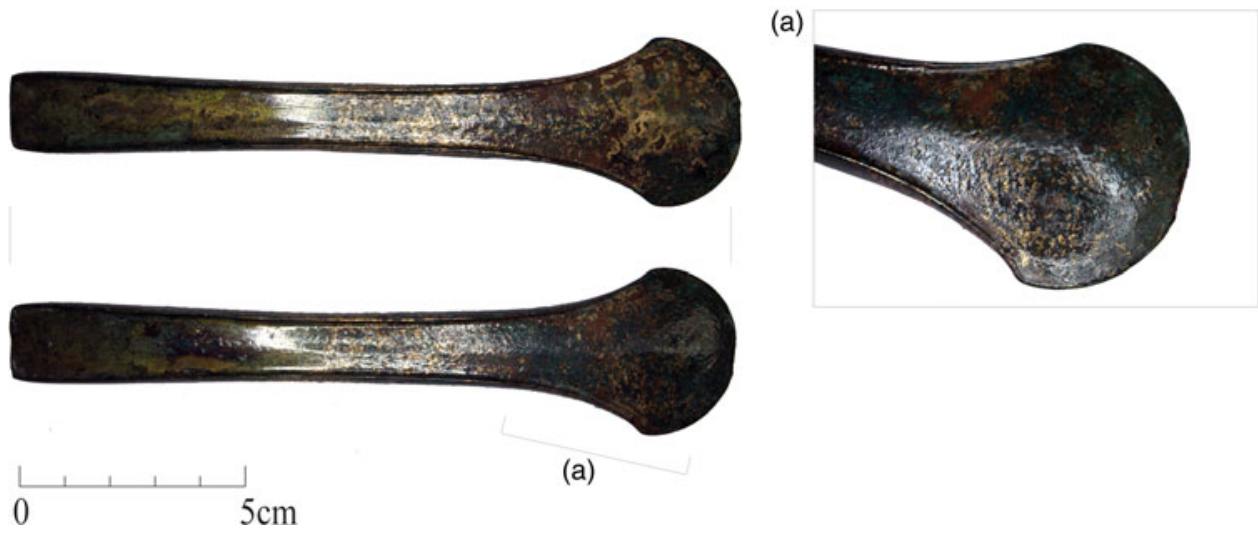

(a)

Figure 2. Axe 280, a type Lausanne, variant Gemeinlebarn, from Gemeinlebarn in Austria, found in a grave (Mayer, 1977: 85, no. 253). Though similar to axe 281, less care was given to the details of this axe. Photographs by the author, courtesy of the Naturhistorisches Museum Wien. 
was added in negative to the model (of wood or wax). If carried out to the standard observed on this axe, all traces of the production process are removed, leaving little evidence for the archaeologists. Whatever the exact technique, they represent additional steps in the chaine operatoire. Scrutinizing the axes more closely, one can see the almost perfect symmetry of axe 281 compared to the cruder shape of axe 280 (from Gemeinlebarn in Austria). The flanges of axe 281 are sharp and well defined. The mid-rib is seamlessly aligned and of an even height. Even the mistake in one of the flanges appears to have been straightened out to some extent (Figure 1b). All in all, compared to axe 280, axe 281 seems to be the product of a more skilled metalworker. That is not to say that axe 280 (Figure 2) does not also demonstrate skill. Obviously, this craftsperson was skilful too, and able to produce a good axe. I simply wish to draw attention to the fact that there are differences between these two axes and that this observation needs to be explained. What we observe here, I argue, are different levels of skill.

Differences in skill are also visible in the form of mistakes. Figure 3 (axe 287, from Meilen in Switzerland) shows an axe with badly fissured flanges. While these cracks would not render the axe useless, they are telling regarding the metalworker's skills. A feature of skill is purposefully constrained physical action (Adamson, 2007: 73). This means, for instance, the proper handling of tools, where the craftsperson does not resort to brute force but coaxes the material into shape (Risatti, 2007: 195). Bronze, when struck, creates a dull tone when it is in a working condition. A high-pitched tone is a (warning) sign that it has become hard and stiff and will not deform any further without cracking, but is in need of annealing (Untracht, 1969: 246). Recognizing such cues from the material are fundamental for its skilful working. This metalworker clearly did not do so and lacked skill in wielding a

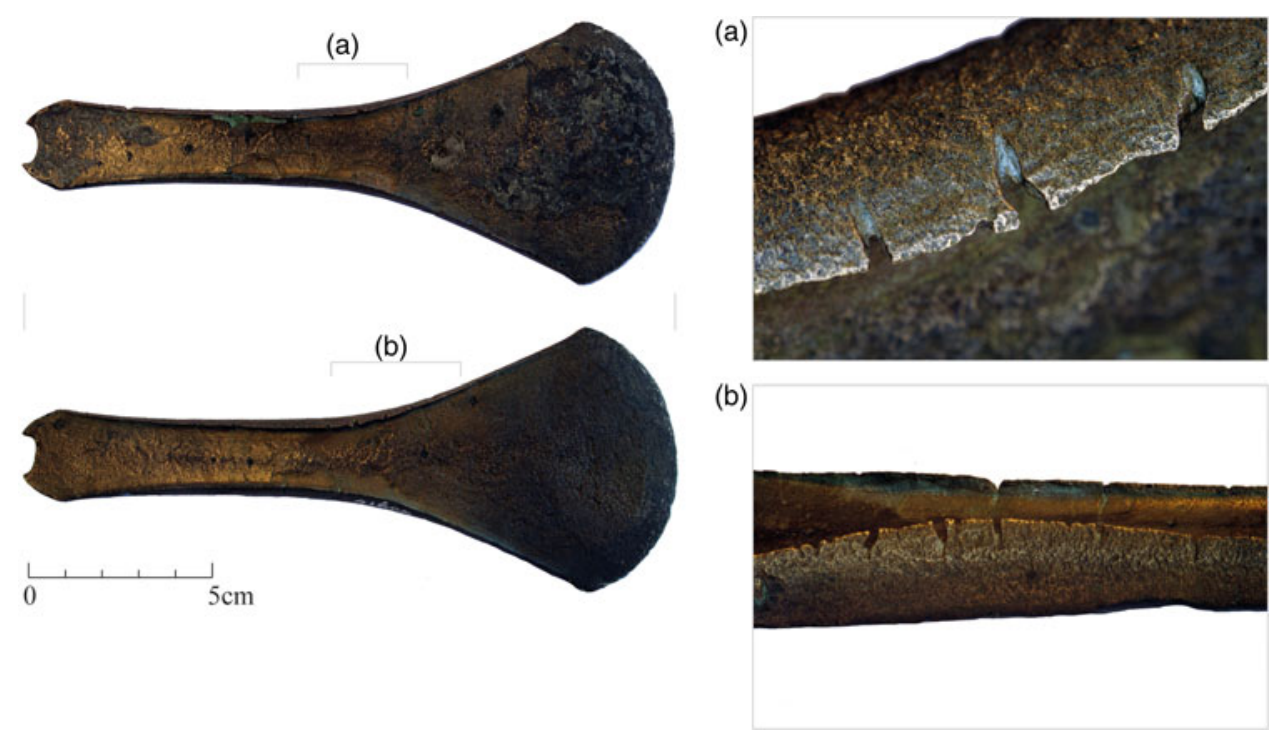

Figure 3. Axe 287, a type Bodensee from Meilen in Switzerland, context unknown (Abels, 1972: 79, no. 538). Note the severe cracking of the flanges due to excessive hammering. Photographs by the author, courtesy of the Landesmuseum Zürich. 
hammer, beating the flanges far too vigorously, which led to cracks. As a comparison, Figure 4 (axe 288, also from Meilen in Switzerland) shows a morphologically very similar axe. This axe has high and sharply creased flanges but without any cracks, demonstrating a distinct variation in skill.

Another example of a mistake is the ostentatious casting fault in axe 153 from Glattfelden in Switzerland (Figure 5). This results from air becoming trapped under the molten copper and reveals a poor casting technique. It shows that this particular axe was cast flat and probably in a mediocre, open mould. Indeed, experiments with casting in open moulds have resulted in similar casting faults, a problem that could, for instance, be solved by setting the mould at an angle and capping it with a flat stone-a solution also known to prehistoric metalworkers (Figueiredo et al., 2016). There are three facets on the flanges of axe 153, indicating a basic, functional finish. The blade is asymmetrical and largely blunt. The overall shape of the axe appears crude and rough compared to its contemporaries (Abels, 1972). Aesthetic considerations, such as symmetry and final polishing, clearly were not of primary concern for this axe.

Nonetheless, according to the metallographic analysis, the axe was worked further despite this casting fault. The blade has seen strong hammer-hardening, seemingly with the aim of creating a harder edge (Kienlin, 2008: 432, sample no. 601501). This took the hardness of the blade far above that of most contemporary axes in the Early Bronze Age (HV [Vickers Hardness test] 260). If axe 153 was made with the intention to produce a functional tool, the quality is probably best assessed on the hardness of the blade. From this mechanical viewpoint alone, this axe should be considered well-made, despite the lack of metallurgical skill implied by the casting fault and careless finish. The resulting qualitatively good tool owes much to the inherent affordances of the material used, a tin-bronze

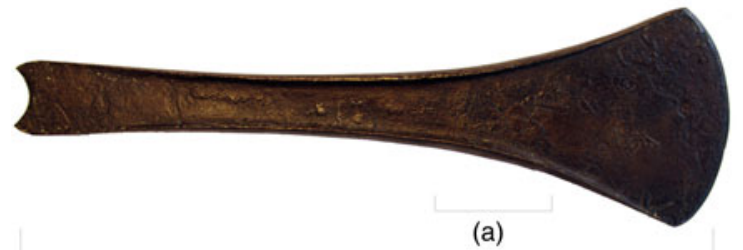

(a)

(b)

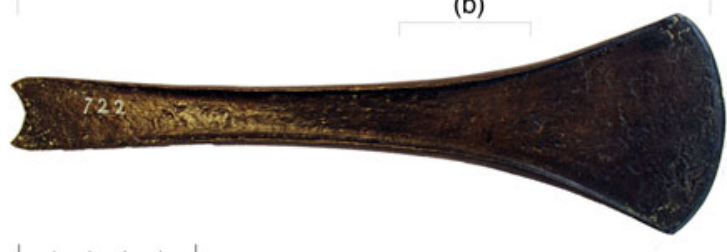

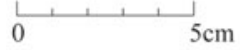

(a)

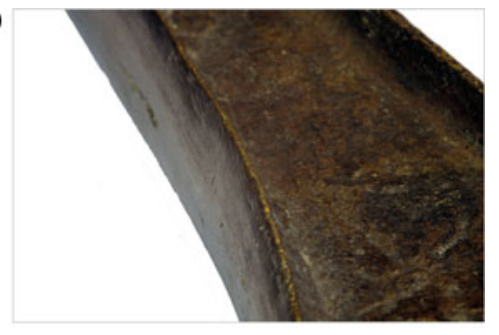

(b)

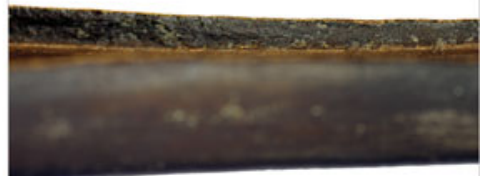

Figure 4. Axe 288, a type Meilen from Meilen in Switzerland, context unknown (Abels, 1972: 41, no. 299). Note the high and sharp contours of the flanges. Photographs by the author, courtesy of the Landesmuseum Zürich. 


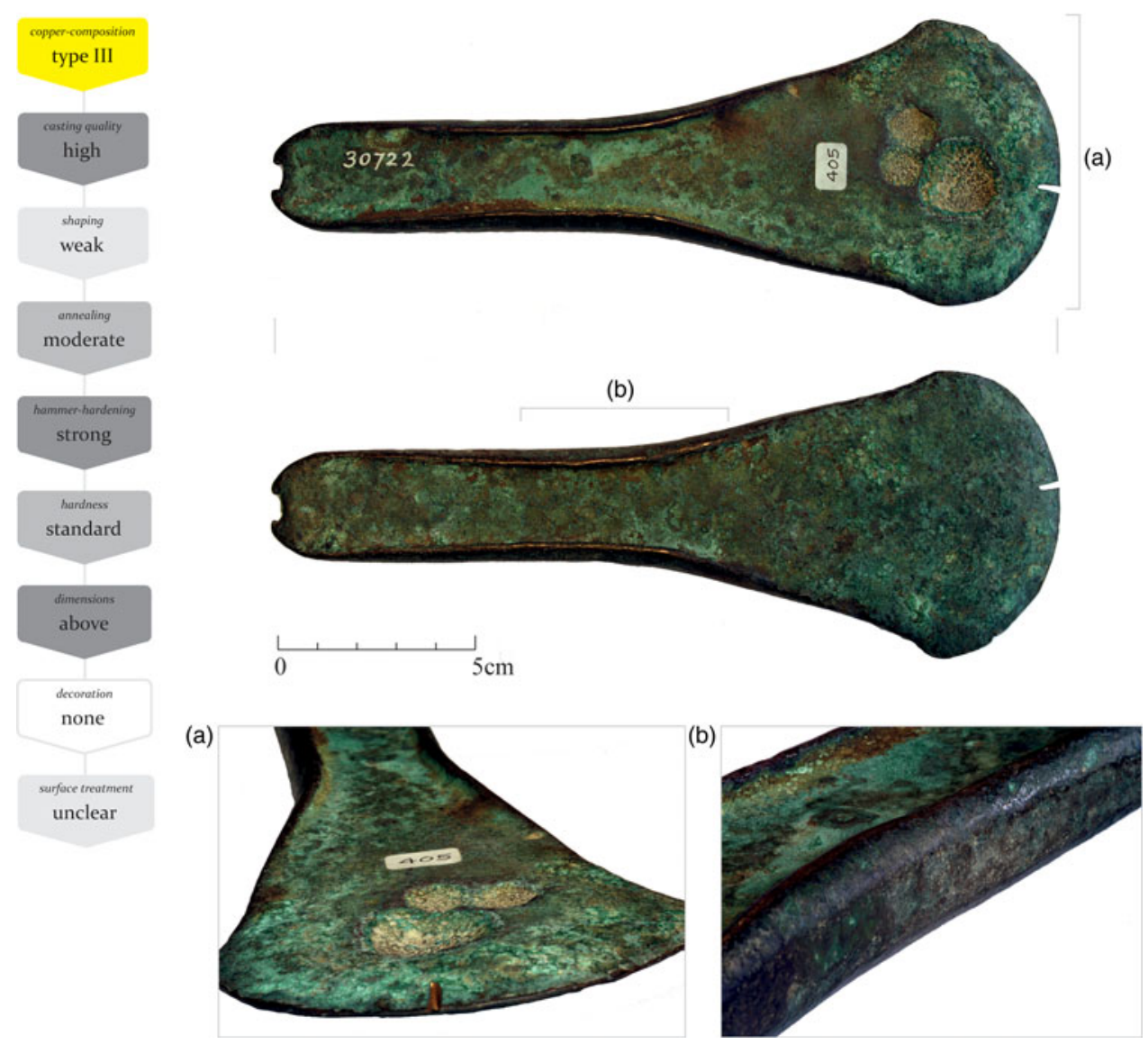

Figure 5. Left: Chaîne opératoire of axe 153. Right: Axe 153, a type Gretchen variant D from Glattfelden in Switzerland, from the banks of the Rhine (Abels, 1972: 82, no. 584). Overall, a very crude axe with major casting errors, roughly worked flanges, and a blunt blade. Photographs by the author, courtesy of the Landesmuseum Zürich.

that hardens well. Axe 153 is a good example of the difficult relationship between quality and skill, a relationship that is subject to the purpose of the object (Kuijpers, 2015a), and the constant tension between correctness and functionality (Sennet, 2009: 45).

A study of skill through metallographic analysis raises further complexities. Take the morphologically comparable axes 3 (from Sennwald-Salez in Switzerland) and 56 (from Sobechleby in the Czech Republic), respectively a type Salez and type Saxon (Stein, 1979; Kienlin, 2008: 45). Metallographic and compositional data show that the similarity is only skindeep. These axes are made from two distinct copper compositions which are perceptibly different from each other. This is an important distinction, as skill is fundamentally dependent on a sensory perception of the material (Kuijpers, 2017). The most obvious difference concerns colour (Lechtman, 1996; Fang \& McDonnell, 2011; Mödlinger et al., in press), but the behaviour of the metal in terms of hardening, malleability, and brittleness is also different. Axe 3 was made of a copper containing a cumulative amount of arsenic, antimony, nickel, and silver of 
$>7$ wt. per cent, making it surprisingly difficult to cast without porosity and to work because of the inherent brittleness caused by this composition (Lechtman, 1996; Kienlin et al., 2006). Axe 56 was made of a copper containing between 5 and 12 per cent tin, a typical tin-bronze that has excellent casting qualities and hardens considerably when hammered (Lechtman, 1996; Wang \& Ottaway, 2004).
Prehistoric craftspeople recognized and appreciated these differences, as can be observed in a chaîne opératoire (Figures 6 and 7). The blade of axe 3 was worked carefully and received a weak hammerhardening only (Kienlin, 2008; 452, sample no. 101202), probably because of the poor casting quality and general brittleness of this material. The flanges probably also saw light hammering to shape them. A

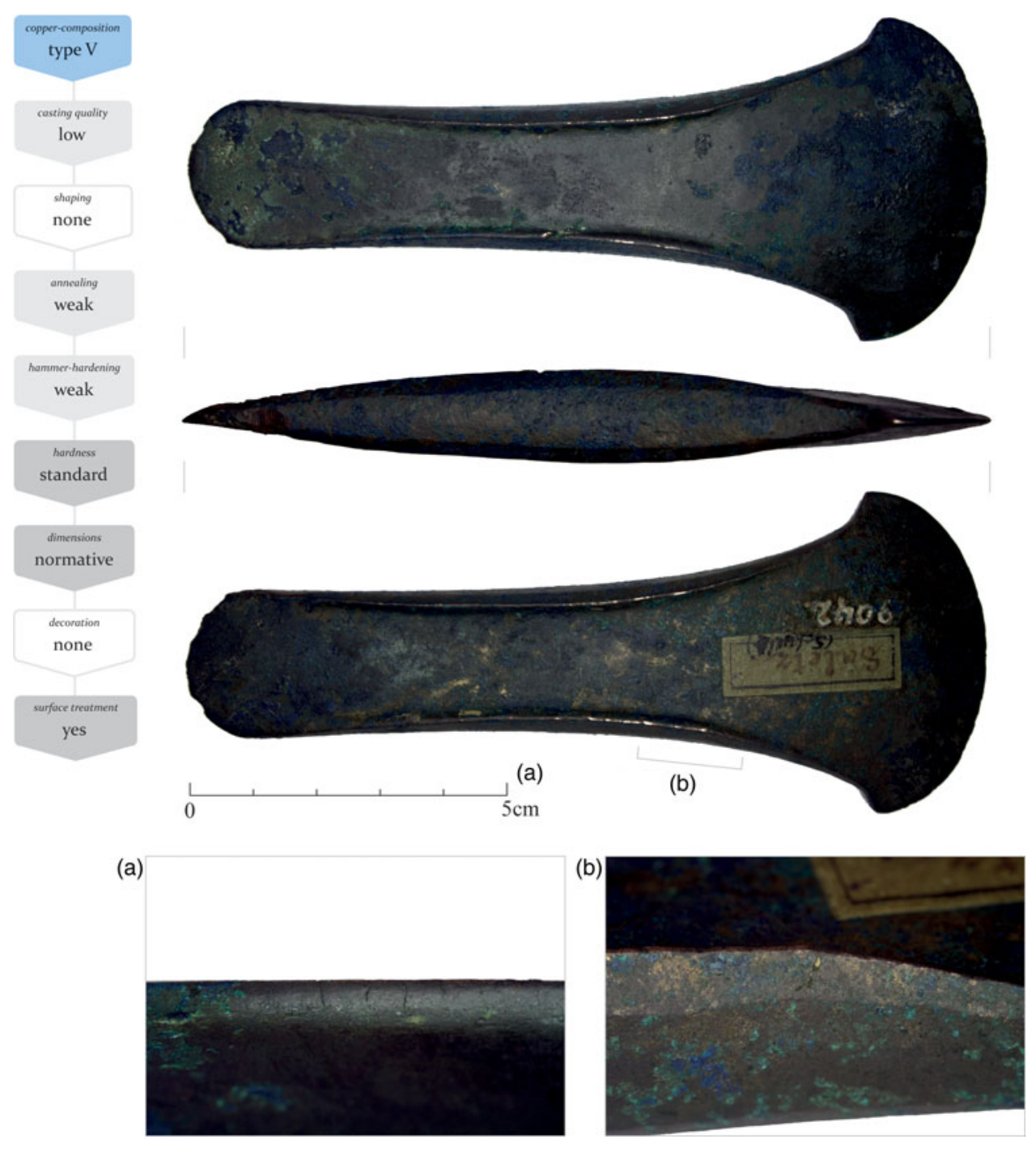

Figure 6. Left: Chaîne opératoire of axe 3. Right: Axe 3, a type Salez from Sennwald-Salez in Switzerland, a hoard find. Note the starting cracks (a) in the flange. Photographs by the author, courtesy of the University of Vienna. 


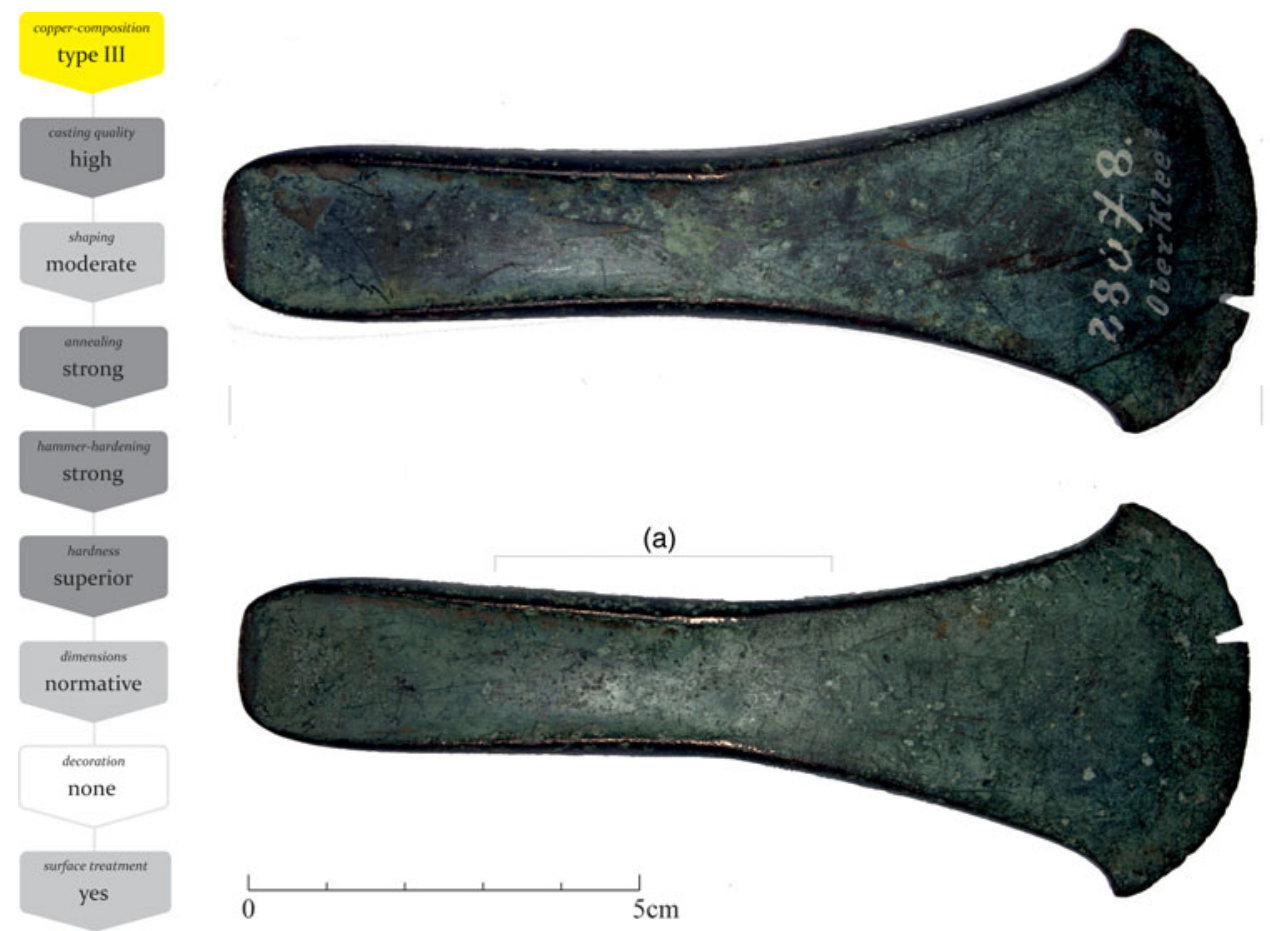

(a)

Figure 7. Left: Chaîne opératoire of axe 56. Right: Axe 56, a type Saxon from Sobechleby in the Czech Republic, a hoard find (Stein, 1979: no. 248). A well-worked axe stressing the qualities of the material it is made from. Photographs by the author, courtesy of the Naturhistorisches Museum Wien.

close look at one flange shows that small cracks appeared (Figure 6a); but, compared to axe 287 , its maker knew exactly when to stop hammering to prevent fractures from developing.

Axe 56 is a high-quality cast that has been hammered to a high total reduction of 70-80 per cent (Kienlin, 2008: 570, sample no. 204201) (reduction being the amount of deformation of the as-cast metal from hammering), which emphasizes the particular affordance, of this material to predictably harden well. At the same time, the metalworker appears to have been aware of the risk of reducing the metal too much in one step. This risk can be noticed because, in the $40-50$ per cent range, the sulphides in tin-bronzes will start deforming, which is felt as a resistance to further deformation and heard because of the slightly higher pitch of the metal (Untracht, 1969: 246; Kuijpers, 2017). Axe 56 was worked exactly up to this point during the final hammer-hardening. About 30-35 per cent reduction took place in one or more rounds of shaping and annealing prior to this final hardening. 
Both of these axes show the recognition of, and response to, specific affordances of the raw material, clear signs of skill.

Lastly, I would like to compare all the above axes to axe 322, from Thun in Switzerland (Figure 8). This elaborate axe distinguishes itself in many ways, except for the fact that it resembles the shape of a normative axe. The copper and gold inlays create a distinct visual appearance, possibly enhanced by patination techniques (Berger, 2012). The chaîne opératoire of this axe is elaborate, incorporating many more steps than any of the above axes. That does not mean that everything was done perfectly. For instance, the axe is very porous, which is likely to be the result of casting in a clay mould that was not baked through and that released gasses when it came into contact with the hot molten metal. The casting quality can, thus, be regarded as poor. This raises the question of whether we are dealing with multiple craftspeople working on the same product, because all the other techniques used on this axe show a high level of skill. Another option is that, given the complexity of the axe (and assuming that it was made by a single person), it is more likely that the shape of the axe was what concerned the craftsperson rather than the casting quality in terms of workability and hardness. Hence, whether or not they saw the casting as a success may have depended more on the visual properties of this axe than its mechanical properties. The inlays of different metals and polychrome effects also point towards an axe that was produced to work in the realm of the visual rather than the practical. Thus, despite variable evidence of technical skill, I follow the well-established argument that this axe was made by a highly skilled specialist (Kristiansen \& Larsson, 2005: 52-53). One can assume that this axe was a prestigious object carrying symbolic, ideological, and/or political meaning (see
Helms, 1993). However, where does that leave all the other axes?

\section{Beyond the specialist; towards skill}

Following this brief examination of Early Bronze Age axes, the question is not whether there were differences in skill, but what to make of these differences. If all axes, from the exceptional Thun axe to the bulk of ordinary axes to sub-standard axes are considered to be the products of specialist metalworkers, the term becomes pointless. How can a single concept cover such divergent axes? The concept of 'specialist' is decidedly inaccurate in light of the variation that can easily be demonstrated. And it is not only in the category of axes that differences in skill can be noticed. More prestigious objects such as swords or neck collars, equally, show wellmade and less well-made examples, and even mistakes (Mödlinger, 2011; Nørgaard, 2015; Bunnefeld, 2016), and such variety has also been noted for Late Neolithic flint daggers, where a similar discussion of craft specialization is taking place (Apel, 2008; Olausson, 2008, 2017).

Taking the above into consideration, and in order to present a more finegrained analysis of the data, I propose a subdivision of the term specialist. The data shows at least four groups of specialists, or degrees of material specialization: ${ }^{1}$

1. Amateurs: products made by these craftspeople demonstrate a basic knowledge of the craft but little refinement. The manner in which certain techniques are applied displays little appreciation of the material, and beginners' mistakes occur. In general, poor

$1 \mathrm{I}$ am indebted to Katharina Botwid, who is working on similar ideas from an approach she calls 'the artisanal perspective' (Botwid, 2016), for some additional insights in the proposed categories. 

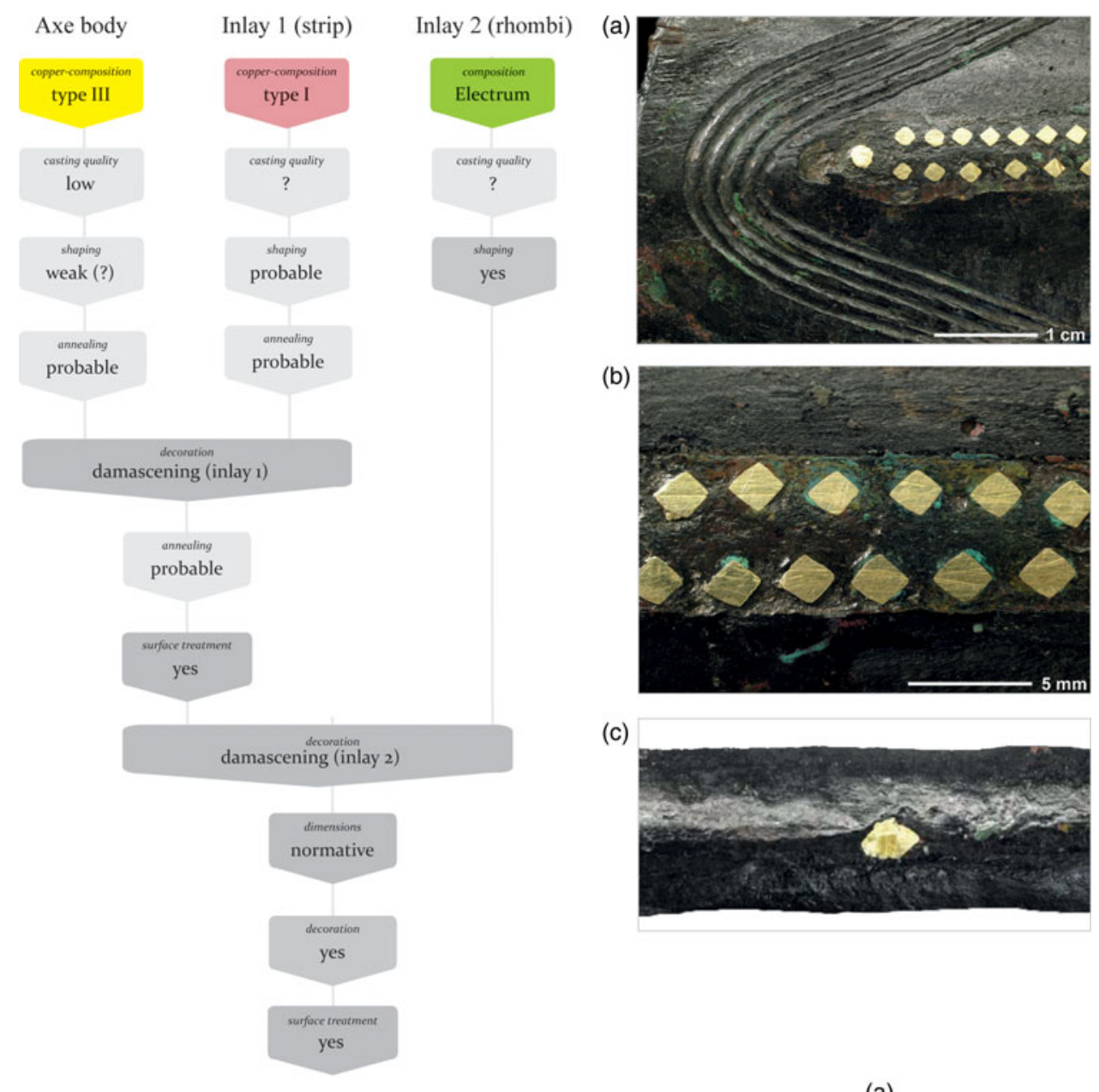

(b)

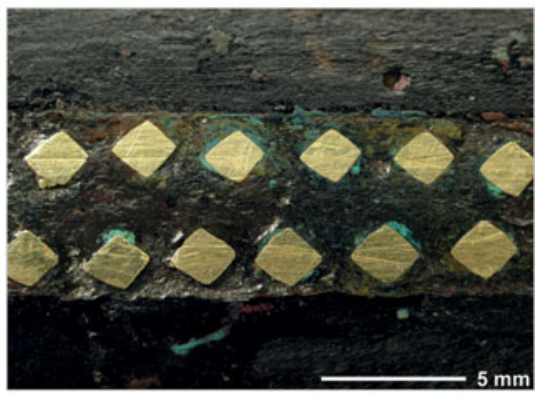

(c)

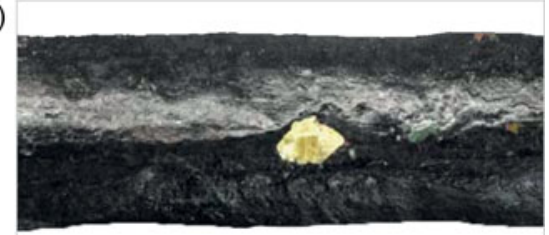

(a)

(b)

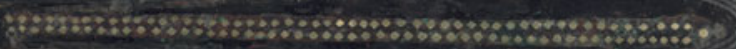

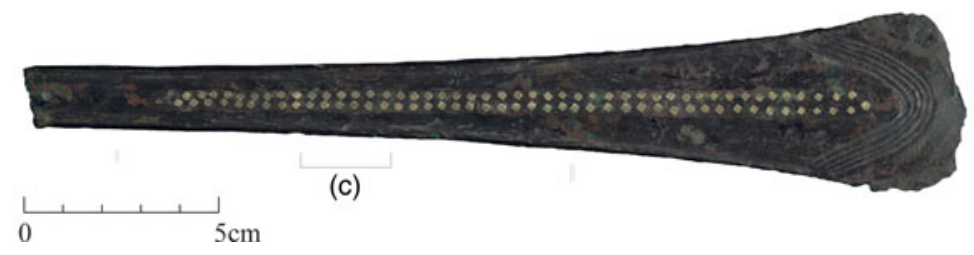

Figure 8. Left: Chaîne opératoire of axe 322. Right and below: Axe 322, a type Rümlang variant A, also known as the Thun-Renzenbübl axe from Thun in Switzerland, from a rich male grave (Abels, 1972: 21, no. 178; Berger et al., 2013). An exceptional axe both in its chaîne opératoire and its appearance. Photographs from Berger, 2012 and Berger et al., 2013, reproduced by kind permission. 
results are to be expected, though they are acceptable (Figures 3 and 5).

2. Common craftspeople: those who have learned the craft. Their skills have become fully embodied but do not stand out. Imitation and repetition are important characteristics of this group and production can be regarded as anonymous. Production tends to be traditional and changes in the technology only occur slowly. These craftspeople produce mostly unoriginal objects and are unlikely to take (aesthetic) risks that would endanger production. The products of this group are of good quality but by no means perfect, and small mistakes occur. Their products serve a function and they simply need to be 'good enough' (Figures 2 and 4).

3. Master crafters: individuals who produce distinct objects that approach a high level of perfection. Their work is likely to be recognized and admired by peers. These objects are not original or unique, however. Rather, the master craftsman is a perfectionist, setting the norm for how an object should look. They are more likely to take greater risks and, therefore, to be innovative and develop new techniques. The qualities, potential, limitations, and risks of the material they work with are clearly appreciated and techniques are adjusted and applied accordingly. Their products blur the boundary between mundane and prestigious. Aesthetics seem to matter. The objects produced by this group stand out from the rest in terms of care, symmetry, surface finish, and decoration (Figures 1, 6, 7).

4. Virtuoso: exceptionally skilled craftspersons capable of creating original or even unique objects through the use of unconventional techniques. Their work explores the very limits of the material. These are the highly skilled artisans who create objects that are likely to be laden with ideological and political meaning, individuals who are admired (or feared) for their exceptional skills by the community, which may lead to a special social status (Helms, 1993). Their objects are original even when referring to unoriginal basic principles. The exceptionally high degree of skills may make it difficult to share these skills among peers and apprentices (Figure 8).

This subdivision into four categories makes it possible to build a more detailed and colourful model, compared to the black and white specialist versus non-specialist framing discussed above. It also draws attention to a large but particularly under-theorized group of artefacts: those made by the anonymous hands of the first and second categories of craftspeople. How this group of objects has escaped our concern will be explained next.

\section{Discussion}

To clarify why this more precise handling of the data with regard to skill is important, we need to see it in light of the generally accepted model in which the Bronze Age is seen as an epoch of increasing social complexity and social stratification, particularly the assumed relationship between a powerful elite and the prestige technology of metalworking (Budd \& Taylor, 1995; Kristiansen \& Larsson, 2005; Vandkilde, 2007). The idea of economic specialization includes the notion of attached specialists who work to produce the weapons and high-status objects of the warrior-aristocracy (Kristiansen \& Larsson, 2005: 53; Earle et al., 2015: 646) and is heavily influenced by the seminal study by Mary Helms, Craft and the Kingly Ideal (1993). Helms is candid about her theoretical framework, which is 
Brumfield and Earle's (1987) political model of specialization and exchange of prestige goods (Helms, 1993: 4). Her thorough anthropological study provides a convincing model for the interpretation of skilled crafting, though this paradigm is critiqued for assuming rather than explaining how certain objects signify prestige (Maurer, 2006: 19-20). It is important to realize that this model is based on particular propositions, one of which is to consider only crafting that is expressed as specialized skills that generally serve nonutilitarian purposes, are imbued by definition with qualities of aesthetics, and are associated with political-ideological activities and symbolism' (Helms, 1993: 6; original emphasis).

In my proposed categories of material specialization, the type of craftspeople Helms describes ('artisans') are in the third and perhaps only in the fourth category of master crafters and virtuosi. Her use of the term 'skilled crafting' is, therefore, a rather unfortunate choice of words in my opinion, especially given her peculiar division "between skilled crafting and manufacturing, between the "true" potter and the man who merely works at making pots' (Helms, 1993: 14-15). Helms does not deal with the ordinary craft objects produced by the largely anonymous group of common craftspeople. There is a distinct Marxist view to be discerned here in which manufacturing resembles little more than unskilled labourers producing commodities.

\section{Extrapolating from Helms: Bronze Age artisans and elites, a story of the one per cent}

Using Helm's model to interpret prehistoric bronze production has certain implications. Axiomatically, this associates the interpreted metal objects with political- ideological activities. It also means that the interpreted objects are uncritically considered to be the products of highly skilled craftspeople because Helms' model does not take into account common craftspeople that produced utilitarian objects.

The particular conceptualization of the skilled specialist (sensu Helms' 'artisan') tallies agreeably with the interests in specialization, exchange, social inequality, and the development of complex societies, a combination of topics that emerged as a new direction in archaeology in the late 1980s (Brumfiel \& Earle, 1987). These became a fundamental issue in the following decade (Price \& Feinman, 1995) and eventually grew into a sweeping interpretation and commonly accepted model of Bronze Age complexity (Kristiansen \& Larsson, 2005; Earle \& Kristiansen, 2010). At the same time, this line of reasoning effectively leaves the bulk of archaeological objects and their makers-the group of common craftspeople and amateurs-unaccounted for. Consequently, current interpretations of Bronze Age metalworking rely on a disproportionate and problematic bias towards exceptionally skilled metalworkers and their objects.

\section{What about diversity?}

Following the proposed distinction of craftspeople from amateur to virtuoso on the basis of skill, I argue that the current 'political economy' model of the Bronze Age fails to fully appreciate a large part of the archaeological record, in particular the common axes and other craft objects produced by ordinary crafters. Emphasizing wealth and prestige objects, this model is in danger of simplifying and polarizing the socio-political structure of prehistoric societies into a narrative that revolves around specialists and elites (e.g. Earle et al., 2015). Non-specialist and non-elites are 
underrepresented (Vandkilde, 2007: 95) because the model builds on a theoretical framework that unevenly appreciates the material culture left behind by Bronze Age people. The diversity of skill suggests the involvement of a large range of craftspeople at various levels of material specialization. Moreover, we need to acknowledge that a large group of objects, such as ordinary axes made by anonymous craftspeople, have had little attention. This category of archaeological data-craft objects that in the first place were supposed to do rather than signify something -is in need of its own theorization.

\section{Conclusions}

Currently, the specialist role of craftspeople is entertained without paying due attention to skill, to the practicalities involved in the craft, and, thus, to objects and the materials these objects were made from. Especially in tandem with an interpretation of the skilled specialist as an artisan (Helms, 1993), a particularly favourable image of craftsmanship emerges, epitomized by a few exceptional pieces at the expense of hundreds of more or less ordinary counterparts.

The appreciation of specialists and interest in the organization of craft in the last few decades have been foremost a question considered in terms of the origins of social inequality. Archaeologists have explored economic specialization rather than material specialization, seeing skill as a time-investment and, thus, as social capital. This idea of specialization is a fundamental building block in the argumentation of (Marxist) models that advocate labour divisions, increased complexity, and social inequality. Not surprisingly, the political economy model for the Bronze Age is, therefore, teeming with specialists. Yet, we do not find specialists, social roles, or economic units in the archaeological record. We mostly recover archaeological objects, some more plentiful than others, from which we observe similarities, differences, and variations in quality.

Though it might not be possible to address skill objectively and quantitatively (but see Budden, 2008; Darmark, 2010), and despite the complex relationship with quality, this does not render an enquiry into skill impossible. A comparison of similar, coeval, Early Bronze Age axes clearly reveals that they differ and these differences go beyond morphology and techniques, thus involving concerns of quality and skill.

Of course, we could interpret all the craftspeople who manufactured the axes presented here as specialists since they all mastered the craft well enough to produce such objects. However, the use of such a sweeping analytical concept collapses all craftspeople into the same category, effectively rendering superfluous a further exploration of the archaeological material. Subsuming the makers of all these axes in this broad category whittles away the differences between them. This, to me, seems antithetical to a discipline that is grounded in careful observations of material culture, some of the most valuable of which are lost if we do not consider this variation.

There is no reason to assume that such differences in skill would not also have been recognized by prehistoric people; thus, our observations may give an insight into what was perceived as quality. Henceforth, one of the main conclusions we should draw is that variability due to the presence or lack of skill is a meaningful difference for archaeologists to explore (Bleed, 2008).

Skill may be a challenging topic, but it is a criterion of specialization that can be delineated through careful observation of archaeological material. Following the 
observed variation between the axes discussed here, I propose four subcategories of material specialization: amateur, craftsperson, master, and virtuoso. These are not meant to completely replace the term 'specialist', but rather they allow for a more nuanced description of the social group of craftspeople when needed. Moreover, they draw specific attention to a large group of artefacts and their producers which are underrepresented in our narratives of the Bronze Age.

Lastly, through an analysis of technical skill and taking a craft perspective, archaeologists may find new ways of exploring the variability in skill and quality that is present in the archaeological record. The results may be surprising; and, in developing such a craft theory, we might find that some of the shibboleths of Marxist archaeologies need nuancing, such as a labour theory of value, and specialization as a path to complexity and social inequality.

\section{ACKNOWLEDGEMENTS}

The work presented here results from my $\mathrm{PhD}$ research, submitted to Cambridge University (2015) and supported by funding from the European Union's Seventh Framework Programme (FP7/ 2007-2013) under grant agreement no. 212402. This article was written at Leiden University as part of the project 'Economies of Destruction' funded by the VICI grant of the Netherlands Organisation for Scientific Research. I would like to thank Marie Louise Sørensen for her overall role as a caring supervisor and for the careful reading and commenting on earlier drafts of this article. David Fontijn is thanked for making several critical but insightful suggestions. I have benefited greatly from discussions with Catalin Popa, Tim Flohr Sørensen, Tobias Kienlin, and Nienke Broekema, exploring the thoughts that underlie this work. Catherine Frieman and three anonymous reviewers helped to tighten the argument.

\section{REFERENCES}

Abels, B.-U. 1972. Die Randleistenbeile in Baden-Württemberg, dem Elsaß, der Franche-Comté und der Schweiz (Prähistorische Bronzefunde IX, 4). München: C.H. Beck.

Adamson, G. 2007. Thinking Through Craft. Oxford: Berg.

Apel, J. 2008. Knowledge, Know-how and Raw Material: The Production of Late Neolithic Flint Daggers in Scandinavia. Journal of Archaeological Method and Theory, 15: 91111. doi:10.1007/s10816-007-9044-2

Berger, D. 2012. Bronzezeitliche Färbetechniken an Metallobjekten nördlich der Alpen. Eine archäometallurgische Studie zur präbistorischen Anwendung von Tauschierung und Patinierung anhand von Artefakten und Experimenten. Halle an der Saale: Landesamt für Denkmalpflege und Archäologie Sachsen-Anhalt, Landesmuseum für Vorgeschichte.

Berger, D., Hunger, K., Bolliger-Schreyer, S., Grolimund, D., Hartmann, S., Hovind, J., et al., 2013. New Insights into Early Bronze Age Damascene Technique North of the Alps. The Antiquaries Journal, 93: 25-53. doi:10.1017/S0003581513000012

Bertemes, F. 2004. Frühe Metallurgen in der Spätkupfer- und Frühbronzezeit. In: H. Meller \& F. Bertemes, eds. Der geschmiedete Himmel. Die weite Welt im Herzen Europas vor 3600 Jabren. Halle: Landesmuseum für Vorgeschichte \& Stuttgart: Theiss, pp. 144-49.

Bill, J. 1997. Die Bronzebeile von Salez. Das 1883 gefundene Depot aus der Frühbronzezeit. Werdenberger Jahrbuch, 10: 247-61.

Bleed, P. 2008. Skill Matters. Journal of Archaeological Method and Theory, 15: 15466. doi:10.1007/s10816-007-9046-0

Botwid, K. 2016. The Artisanal Perspective in Action: An Archaeology in Practice (Acta Archaeologica Ludensia Series in $8^{\circ} 66$ ). Lund: Lund University.

Bray, P. 2012. Before 29Cu became Copper: Tracing the Recognition and Invention of 
Metalleity in Britain and Ireland during the 3rd Millennium BC. In: M.J. Allen, J. Gardiner, \& A. Sheridan, eds. Is There a British Chalcolithic? People, Place and Polity in the later Third Millennium (Prehistoric Society Research Paper 4). Oxford: Oxbow Books, pp. 56-70.

Brumfiel, E.M. \& Earle, T.K. eds. 1987. Specialization, Exchange and Complex Societies. Cambridge: Cambridge University Press.

Brysbaert, A. \& Gorgues, A. 2017. Artisans versus Nobility? Multiple Identities of Elites and 'Commoners' Viewed through the Lens of Crafting from the Chalcolithic. Leiden: Sidestone Press.

Budd, P. \& Taylor, T. 1995. The Faerie Smith Meets the Bronze Industry: Magic versus Science in the Interpretation of Prehistoric Metal-making. World Archaeology, 27: 133-43. doi:10.1080/ 00438243.1995 .9980297

Budden, S. 2008. Skill amongst the Sherds: Understanding the Role of Skill in the Early to Late Middle Bronze Age in Hungary. In: I. Berg, ed. Breaking the Mould: Challenging the Past through Pottery (BAR International Series 1861). Oxford: Archaeopress, pp. 1-17.

Bunnefeld, J.-H. 2016. Crafting Swords: The Emergence and Production of Full-hilted Swords in the Early Nordic Bronze Age. Praehistorische Zeitschrift, 91: 379-430. doi:10.1515/pz-2016-0023

Childe, V.G. 1963. The Bronze Age. New York: Biblo \& Tannen.

Childe, V.G. 1965. Man Makes Himself (4th ed). London: Watts.

Cordes, C. 2005. Veblen's 'Instinct of Workmanship', its Cognitive Foundations, and Some Implications for Economic Theory. Journal of Economic Issues, 39: 120. doi:10.1080/00213624.2005.11506778

Costin, C.L. 1991. Craft Specialization: Issues in Defining, Documenting, and Explaining the Organization of Production. Archaeological Method and Theory, 3: 1-56.

Costin, C.L. 2001. Craft Production Systems. In: G.M. Feinman \& D. Price, eds. Archaeology at the Millennium: $A$ Sourcebook. New York: Kluwer Academic/ Plenum, pp. 273-329.

Costin, C.L. 2007. Thinking about Production: Phenomenological Classification and Lexical Semantics. Archaeological Papers of the American Anthropological Association, 17: 143-62. doi:10.1525/ap3a.2007.17.1.143

Costin, C.L. \& Wright, R.P. eds. 1998. Craft and Social Identity (Archaeological Papers of the American Anthropological Association 8). Arlington (VA): American Anthropological Association.

Crawford, M. 2009. Shop Class as Soulcraft: An Inquiry into the Value of Work. New York: Penguin.

Darmark, K. 2010. Measuring Skill in the Production of Bifacial Pressure Flaked Points: A Multivariate Approach using the Flip-test. Journal of Archaeological Science, 37: 2308-15. doi:10.1016/j. jas.2010.04.004

Earle, T., Ling, J., Uhnér, C., Stos-Gale, Z.\& Melheim, L. 2015. The Political Economy and Metal Trade in Bronze Age Europe: Understanding Regional Variability in Terms of Comparative Advantages and Articulations. European Journal of Archaeology, 18: 633-57. doi: 10.1179/1461957115Y.0000000008

Earle, T.K. \& Kristiansen, K. eds. 2010. Organizing Bronze Age Societies: The Mediterranean, Central Europe, and Scandinavia Compared. Cambridge: Cambridge University Press.

Fang, J.-L. \& McDonnell, G. 2011. The Colour of Copper Alloys. Historical Metallurgy, 45: 52-61.

Figueiredo, E., Pereira, M.A.S., Lopes, F., Marques, J. G.., Santos, J. P., Araújo, M. F., et al. 2016. Investigating Early/Middle Bronze Age Copper and Bronze Axes by Micro X-ray Fluorescence Spectrometry and Neutron Imaging Techniques. Spectrochimica Acta Part B: Atomic Spectroscopy, 122: 15-22. doi: 10.1016/j. sab.2016.05.002

Graeber, D. 2001. Toward an Anthropological Theory of Value: The False Coin of Our Own Dreams. New York: Palgrave.

Hansen, S. 2013. Innovative Metals: Copper, Gold, and Silver in the Black Sea Region and the Carpathian Basin During the 5th and 4th Millennium BC. In: S. Burmeister, S. Hansen, M. Kunst, \& N. M. MüllerScheessel, eds. Metal Matters: Innovative Technologies and Social Change in Prehistory and Antiquity. Rahden/Westfalen: Verlag Marie Leidorf GmbH, pp. 137-70.

Hansen, S. 2016. Innovationen und Wissenstransfer in der frühen Metallurgie 
des westlichen Eurasiens. In: S. Terna \& B. Govedarica, eds. Interactions, Changes, and Meanings: Essays in Honour of Igor Manzura on the Occasion of his 60th Birthday. Kishinev: Stratum, pp 10720.

Helms, M.W. 1993. Craft and the Kingly Ideal: Art, Trade, and Power. Austin: University of Texas Press.

Hruby, Z.X. \& Flad, R.K. eds. 2007. Rethinking Craft Specialization in Complex Societies: Archaeological Analyses of the Social Meaning of Production (Archaeological Papers of the American Anthropological Association 17). Berkeley: University of California Press.

Kahneman, D. 2012. Thinking, Fast and Slow. London: Penguin.

Kienlin, T.L. 2006. Waffe - Werkzeug Barren: Zur Deutung frühbronzezeitlicher Randleistenbeilein Depotfunden des nordalpinen Raums. In: H.-P. Wotzka, ed. Grundlegungen. Beiträge zur Europäischen und Afrikanischen Archäologie für Manfred K.H. Eggert. Tübingen: Francke, pp. 461-76.

Kienlin, T.L. 2008. Frühes Metall im Nordalpinen Raum. Eine Untersuchung zu technologischen und kognitiven Aspekten früher Metallurgie anband der Gefüge frübbronzezeitlicher Beile (Universitätsforschungen zur prähistorischen Archäologie). Bonn: Rudolf Habelt.

Kienlin, T.L. 2010. Traditions and Transformations: Approaches to Eneolithic (Copper Age) and Bronze Age Metalworking and Society in Eastern Central Europe and the Carpathian Basin (BAR International Series 2184). Oxford: Archaeopress.

Kienlin, T.L., Bischoff, E. \& Opielka, H. 2006. Copper and Bronze during the Eneolithic and Early Bronze Age: A Metallographic Examination of Axes from the Northalpine Region. Archaeometry, 48: 453-68. doi: 10.1111/j.1475-4754.2006.00266.x

Krause, R. 1988. Die endneolithischen und frübbronzezeitlichen Grabfunde auf der Nordstadtterrasse von Singen am Hohentwiel, Grabfunde von Singen am Hohentwiel. Stuttgart: Theiss.

Kristiansen, K. 1987. From Stone to Bronze: The Evolution of Social Complexity in Northern Europe, 2300-1200 BC. In: E.M. Brumfiel \& T. Earle, eds. Specialization, Exchange, and Complex Societies.
Cambridge: Cambridge University Press, pp. 30-51.

Kristiansen, K. 2017. Interpreting Bronze Age Trade and Migration. In: E. Kiriatzi, \& C. Knappett, eds. Human Mobility and Technological Transfer in the Prehistoric Mediterranean (British School at Athens Studies in Greek Antiquity). Cambridge: Cambridge University Press, pp. 154-80.

Kristiansen, K. \& Earle, T. 2015. Neolithic versus Bronze Age Social Formations: A Political Economy Approach. In: K. Kristiansen, L. Smejda \& J. Turek, eds. Paradigm Found: Archaeological Theory Present, Past and Future. Essays in Honour of Evžen Neustupný. Oxford: Oxbow Books, pp. 234-47.

Kristiansen, K. \& Larsson, B. 2005. The Rise of Bronze Age Society: Travels, Transmissions and Transformations. Cambridge: Cambridge University Press.

Kristiansen, K. \& Suchowska-Ducke, P. 2015. Connected Histories: The Dynamics of Bronze Age Interaction and Trade 15001100 BC. Proceedings of the Prehistoric Society, 81: 361-92. doi:10.1017/ppr.2015.17

Kuijpers, M.H.G. 2008. Bronze Age Metalworking in the Netherlands (c. 2000800 BC): A Research into the Preservation of Metallurgy Related Artefacts and the Social Position of the Smith. Leiden: Sidestone Press.

Kuijpers, M.H.G. 2015a. Some Thoughts on Quality and Skill in Early Bronze Age Axes. In: E.A.G. Ball \& S. Arnoldussen, eds. Metaaltijden 2. Bijdragen in de Studie van de Metaaltijden. Leiden: Sidestone Press, pp. 19-29.

Kuijpers, M.H.G. 2015b. Contradicting Context: Understanding Early Bronze Axes from the Perspective of Production. In: P. Suchowska-Ducke, S.S. Reiter \& H. Vandkilde, eds. Forging Identities: The Mobility of Culture in Bronze Age Europe, Volume 1 (BAR International Series. 2771-2). Oxford: Archaeopress, pp. 20312.

Kuijpers, M.H.G. 2017. An Archaeology of Skill: Metalworking Skill and Material Specialization Based on Late Copper Age and Early Bronze Age Axes from Central Europe. Abingdon: Routledge.

Lambek, M. 2013. The Value of (Performative) Acts. HAU, Journal of Ethnographic Theory, 3: 141-60. doi:10.14318/hau3.2.009 
Lechtman, H. 1996. Arsenic Bronze: Dirty Copper or Chosen Alloy? A View from the Americas. Journal of Field Archaeology, 23: 477-514. doi:10.2307/530550

Martinón-Torres, M. \& Uribe-Villegas, M.A. 2015. Technology and Culture in the Invention of Lost-wax Casting in South America: An Archaeometric and Ethnoarchaeological Perspective. Cambridge Archaeological Journal, 25: 37790. doi:10.1017/S0959774314001164

Maurer, B. 2006. In the Matter of Marxism. In: C. Tilley, W. Keane, S. Küchler, M. Rowlands \& P. Spyer, eds. Handbook of Material Culture. London: SAGE Publications, pp. 13-29.

Mayer, E.F. 1977. Die Äxte und Beile in Österreich (Prähistorische Bronzefunde IX, 9). München: C.H. Beck.

Mödlinger, M. 2011. Herstellung und Verwendung bronzezeitlicher Schwerter Mitteleuropas: eine vertiefende Studie zur mittelbronze- und urnenfelderzeitlichen Bewaffnung und Sozialstruktur (Universitätsforschungen zur prähistorischen Archäologie). Bonn: Rudolf Habelt.

Mödlinger, M., Kuijpers, M.H.G., \& Berger, D. in press. Quantitative Research on the Colour of $\mathrm{Cu}-\mathrm{As}, \mathrm{Cu}-\mathrm{Sn}, \mathrm{Cu}-\mathrm{Ni}$, and $\mathrm{Cu}-\mathrm{Sb}$ Alloys. Journal of Archaeological Science.

Naveh, D. \& Bird-David, N. 2014. How Persons Become Things: Economic and Epistemological Changes Among Nayaka Hunter-gatherers. Journal of the Royal Anthropological Institute, 20(1): 74-92. doi: 10.1111/1467-9655.12080

Nessel, B. 2012. Metallurgen im Grab- Überlegungen zur sozialen Einstufung handwerklicher Spezialisten. In: T.L. Kienlin \& A. Zimmermann, eds. Beyond Elites: Alternatives to Hierarchical Systems in Modelling Social Formations. International Conference at the Ruhr-Universität Bochum, Germany, October 22-24, 2009 (Universitätsforschungen zur prähistorischen Archäologie). Bonn: Rudolf Habelt, pp. 423-32.

Nørgaard, H.W. 2015. Metalcraft within the Nordic Bronze Age: Combined Metallographic and Superficial Imaging Reveals the Technical Repertoire in Crafting Bronze Ornaments. Journal of Archaeological Science, 64: 110-28. doi:10.1016/j. jas.2015.10.005
Olausson, D.J. 2008. Does Practice Make Perfect? Craft Expertise as a Factor in Aggrandizer Strategies. Journal of Archaeological Method and Theory, 15: 2850. doi:10.1007/s10816-007-9049-x

Olausson, D. 2013. The Flintknapper and the Bronzesmith. In: S. Bergerbrant \& S. Sabatini, eds. Counterpoint: Essays in Archaeology and Heritage Studies in Honour of Professor Kristian Kristiansen (BAR International Series 2508). Oxford: Archaeopress, pp. 447-56.

Olausson, D. 2017. Knapping Skill and Craft Specialization in Late Neolithic Flint Daggers. Lithic Technology. doi:10.1080/ 01977261.2017.1364328

Ottaway, B.S. 2001. Innovation, Production, and Specialisation in Early Prehistoric Copper Metallurgy. European Journal of Archaeology, 4: 87-112.

Price, D. \& Feinman, G.M. eds. 1995. Foundations of Social Inequality. New York: Plenum.

Risatti, H. 2007. A Theory of Craft. Chapel Hill: The University of North Carolina Press.

Ritzer, G. 2010. Focusing on the Prosumer: On Correcting an Error in the History of Social Theory. In: B. Blättel-Mink \& K.U. Hellmann, eds. Prosumer Revisited. Zur Aktualität einer Debatte. Wiesbaden: VS Verlag für Sozialwissenschaften, pp. 6179. doi:10.1007/978-3-531-91998-0_3

Rowlands, M.J. 1971. The Archaeological Interpretation of Prehistoric Metalworking. World Archaeology, 3: 210-23.

Rowlands, M.J. 1984. Conceptualizing the European Bronze and Early Iron Age. In: J.L. Bintliff, ed. European Social Evolution: Archaeological Perspectives. Bradford: University of Bradford, pp. 147-56.

Sennett, R. 2009. The Craftsman. London: Penguin.

Sofaer, J.R. 2006. Pots, Houses, and Metal: Technological Relations at the Bronze Age Tell at Százhalombatta, Hungary. Oxford Journal of Archaeology, 25: 127-47. doi:10.1111/j.1468-0092.2006.00253.x

Sofaer, J.R. 2010. Technology and Craft. In: T. Earle \& K. Kristiansen, eds. Organizing Bronze Age Societies: The Mediterranean, Central Europe, and Scandinavia Compared. Cambridge: Cambridge University Press, pp. 185-217. 
Sofaer, J.R. \& Budden, S. 2013. Many Hands Make Light Work: Potting and Embodied Knowledge at the Bronze Age Tell at Százhalombatta, Hungary. In: M.L.S. Sørensen \& K. Rebay-Salisbury, eds. Embodied Knowledge: Historical Perspectives on Belief and Technology. Oxford: Oxbow Books, pp. 117-27.

Stein, F. 1979. Katalog der vorgeschichtlichen Hortfunde in Süddeutschland (Saarbrücker Beiträge zur Altertumskunde). Bonn: Rudolf Habelt.

Untracht, O. 1969. Metal Techniques for Craftsmen: A Basic Manual for Craftsmen on the Methods of Forming and Decorating Metals (reprinted 2010). London: Robert Hale.

Vandkilde, H. 2007. Culture and Change in Central European Prehistory: 6th to 1st Millennium BC. Aarhus: Aarhus University Press.

Vandkilde, H. 2016. Bronzization: The Bronze Age as Pre-Modern Globalization. Praehistorische Zeitschrift, 91: 103-23. doi: 10.1515/pz-2016-0005

Wang, Q. \& Ottaway, B.S. 2004. Casting Experiments and Microstructure of Archaeologically Relevant Bronzes (BAR International Series 1331). Oxford: Archaeopress.

Wendrich, W. 2012. Archaeology and Apprenticeship: Body Knowledge,
Identity, and Communities of Practice. In: W. Wendrich, ed. Archaeology and Apprenticeship: Body Knowledge, Identity, and Communities of Practice. Tucson: University of Arizona Press, pp. 1-20.

\section{Biographical Notes}

Maikel Kuijpers holds a PhD from Cambridge University and is currently a lecturer in European Prehistory at the Faculty of Archaeology, Leiden University. His main research topics are technology, craftsmanship, and skill, which he explores both in archaeology and in contemporary society. As part of the 'Economies of Destruction' project, his research focuses on the production of bronze objects that were deposited throughout Europe, and the involvement of the metalworker in this phenomenon.

Address: Faculty of Archaeology, Leiden University, Einsteinweg 2, 2333 CC, Leiden, The Netherlands. [email: m.h.g. kuijpers@arch.leidenuniv.nl]

\section{L'âge du Bronze, un monde de spécialistes ? Le travail du métal à travers le prisme des compétences et de la spécialisation}

Le constat que le personnage du "spécialiste " en tant qu'entité sociale constitue une unité analytique importante en archéologie typiquement employée pour expliquer l'organisation sociale de la production dans une perspective Marxiste forme le point de départ de cet article. Ceci a causé une certaine fossilisation autour de préoccupations économiques plutôt que matérielles. Ici on soutiendra que la notion de " spécialiste » est devenue trop conceptuelle et ne reflète plus vraiment la réalité archéologique. Ainsi, sur la base d'une brève étude de haches de l'Age du Bronze ancien, lobjectif est de mettre en valeur les compétences techniques pour démontrer qu'il existe divers degrés de spécialisation. Il nous faut donc aller au-delà du terme parapluie de "spécialiste » et utiliser des unités analytiques plus précises et mieux adaptées à l'étude de la diversité de la culture matérielle. Quatre degrés de spécialisation sont proposés: l'amateur, avec des connaissances de base mais sans distinction; l'artisan qui produit des objets pratiques et bien finis; le maître artisan, à la recherche de la perfection et établissant les normes; le virtuose qui prend des risques en créant des objets originaux et uniques. Translation by Madeleine Hummler

Mots-clés: spécialiste, spécialisation matérielle, théorie de l'artisanat, compétences, âge du Bronze, chaîne opératoire 


\section{Die Bronzezeit, eine Welt von Spezialisten? Die Metallbearbeitung aus der Sicht der Fähigkeiten und der materiellen Spezialisierung}

Die Tatsache, dass die gesellschaftliche Rolle des "Spezialisten” eine wichtige analytische Einheit in der Archäologie darstellt, die man typisch in marxistischen Deutungen der sozialen (bandwerklichen) Organisation anwendet, bildet der Ausgangspunkt dieses Artikels. Eine gewisse Kristallisierung dieses Konzeptes in Bezug auf wirtschaftliche und weniger auf materielle Aspekte hat sich daraus ergeben. Hier wird der Standpunkt vertreten, dass der "Spezialist” einen zu dominierenden Begriff geworden ist, der nicht mehr in den archäologischen Artefakten verwurzelt ist. Demzufolge wird hier anhand einer kurzen Erforschung von frübbronzezeitlichen Beilen versucht, die technischen Fachkenntnisse hervorzubeben, um verschiedene Stufen der materiellen Spezialisierung deutlich zu machen. Deshalb wird hier vorgeschlagen, dass man über den Sammelbegriff von "Spezialist" binausgeht und genauere analytische Einheiten anwendet, welche die qualitative Vielfalt der materiellen Kultur besser erfassen können. Vier solche Stufen werden vorgeschlagen: der Amateur, der Grundkenntnisse aber wenig Geschicktheit besitzt; der Fachmann, der gute, praktische Gegenstände herstellt; der Meister, der nach Perfektion strebt und die Normen setzt; der Virtuose, der bereit ist, Risiko einzugehen, um originelle und einzigartige Erzeugnisse zu schaffen. Translation by Madeleine Hummler

Stichworte: Spezialist, materielle Spezialisierung, Theorie des Handwerks, Fähigkeit, Bronzezeit, chấne opératoire 